\title{
KARAKTERISTIK MAKANAN PENDAMPING ASI INSTAN LOKAL MENGGUNAKAN CAMPURAN TEPUNG BERAS MERAH DAN TEPUNG DAUN KELOR (Moring olifera)
}

\author{
Zakaria $^{1}$, Ramlan Asbar ${ }^{1}$, Sukmawati ${ }^{1}$, Sarmila ${ }^{2}$ \\ ${ }^{1}$ Jurusan Gizi, Politeknik Kesehatan Kemenkes, Makassar \\ ${ }^{2}$ Alumni Sarjana Terapan Gizi, Politeknik Kesehatan Kemenkes, Makassar \\ Correspondence : zakariagizi@gmail.com/08124283022
}

\begin{abstract}
One of the causes of malnutrition in children is a habitual pattern of complementary feeding of breast milk is inappropriate, the ignorance about the ways of feeding in infants and the low quantity and quality of the complementary food that given to children. The purpose of the research is to find out the characteristics of quality of chemical (nutrient), physical, acceptability of complementary food by using local uses instant Brown rice flour and moringa leaf flour. The research method is postest only, formulations namely F1 (75: 5), F2 (72.5: 7.5), F3 (70:10), and F4 (67, 5: 12,5) to supply per $100 \mathrm{~g}$ of ingredients and complete the nutritional content using full cream powder $15 \mathrm{~g}$ and sugar $5 \mathrm{~g}$. The nutrient content of the raw material of brown rice and moringa leafflour was analyzed proximate in the laboratory, full cream milk powder and sugar using the nutrient composition of the literature source. The best product analysis uses the De Garmo effectiveness method. The results showed that formula of complementary food with the best local Instant value 0.59, namely Formula 1 with consecutive energy nutrient $393.2 \mathrm{kcal}$, protein $9.3 \mathrm{~g}$, fat $9.4 \mathrm{~g}$, carbohydrate 56.3 $\mathrm{g}$, fiber $16.33 \mathrm{~g}$, moisture content $5.4 \%$, grey levels $8.5 \%$. Characteristics of the physical density of kamba $0.5 \mathrm{~g} / \mathrm{ml}$ and water absorption $1 \mathrm{ml} / \mathrm{g}$. Physical characteristics based on the density of $0.5 \mathrm{~g} / \mathrm{ml}$ and water absorption $1 \mathrm{ml} / \mathrm{g}$. The power to receive the best formula based on aspects of color, aroma, texture, taste is received (liked) by the panellists
\end{abstract}

Keywords : Instant, complementary food, Moringa

\section{PENDAHULUAN}

Masalah gizi di Indonesia merupakan masalah yang masih belum teratasi, terutama untuk kelompok rentan gizi. kelompok rentan gizi merupakan sekelompok orang yang membutuhkan penanganan khusus dalam pemenuhan kebutuhan dasar salah satunya bayi, dan balita. Masalah gizi yang masih belum teratasi pada balita antara lain stunting dan gizi kurang, (Kementerian Kesehatan RI 2012).
Hasil Pemantauan Status Gizi (PSG) tahun 2016, di Indonesia menunjukkan bahwa anak usia 0-23 bulan terdapat 11,8 $\%$ anak yang mengalami gizi kurang dan $3,1 \%$ gizi buruk. Sementara itu anak sangat pendek $7,1 \%$ dan pendek $14,6 \%$, serta anak sangat kurus 3,7 \% dan kurus $8,9 \%$. Provinsi Sulawesi Selatan menunjukkan bahwa anak usia 0-23 bulan terdapat $16,5 \%$ anak yang mengalamii gizi kurang dan 4,4\% yang gizi buruk. Sementara itu sangat pendek $7,6 \%$, dan pendek $19,1 \%$ dan anak sangat kurus 2,7 
$\%$ dan yang kurus 8,3 \% (Kementerian Kesehatan RI, 2017).

Peningkatan kebutuhan energi bayi usia enam bulan yaitu sebesar $24-30 \%$ dibandingkan dengan kebutuhan saat usia 3-5 bulan. Agar pertumbuhan bayi tidak terhenti ataupun melambat, maka kebutuhan gizi mutlak harus terpenuhi sesuai dengan kebutuhan bayi, pada enam bulan keatas untuk memenuhi kebutuhan zat gizi karena rawan terjadi kekurangan zat gizi tertentu. Salah satu bentuk MP-ASI yang hygienis, praktis disajikan, dan dikenal masyarakat adalah bubuk instan (Ratna, dkk, 2014).

Hasil penelitian Zakaria (2012) yang menyimpulkan bahwa dengan penambahan tepung daun kelor pada makanan atau minuman anak balita gizi kurang sebanyak $3-5 \mathrm{~g}$ dapat memicu nafsu makan anak sehingga porsi makanan yang dikonsumsinya dapat meningkat dengan demikian berdampak pada pertambahan berat badan anak.

Penelitian ini bertujuan untuk mengetahui karakteristik kimia (kandungan zat gizi), karaktersitik fisik, dan daya terima dari makanan pendamping air susu ibu (MP-ASI) instan lokal menggunakan campuran tepung beras merah dan tepung daun kelor.

\section{METODE PENELITIAN}

Penelitian ini merupakan penelitian Eksperimen dengan menggunakan Rancangan Acak Lengkap (RAL) 1 Faktor. Bahan utama yaitu beras merah dengan karakteristik bersih dan tidak berbau yang diperoleh dari pasar daya dan daun kelor yang segar berwarna hijau muda dan tua diperoleh dari kebun kelor Kampus Jurusan gizi Poltekkes Makassar. Bahan pendukung pembuatan bubuk terdiri atas susu full cream, dan gula pasir yang dibeli dari pasar swalayan, bahan kimia yaitu aquadest serta bahan-bahan untuk analisis fisik produk. Bahan-bahan untuk analisis kimia diantaranya aquades, air bebas ion, asam sulfat (H2SO4), HCL, $\mathrm{NaOH}$. Peralatan yang digunakan dalam penelitian terdiri atas peralatan untuk membuat tepung beras merah, tepung daun kelor, bubuk instan adalah timbangan digital sebagai alat timbangan bahan, baskom sebagai wadah pencampuran bahan, kompor dan panci sebagai alat masak, cabinet dryer sebagai alat pengering bahan, blender untuk menghancurkan bahan, dan ayakan 60 mesh untuk menghasilkan tepung halus dan alat untuk analisis sifat fisik dan analisis kadar protein dengan labu kjeldahl, timbangan analitik, Erlenmeyer, oven, tabung sentrifuse, gelas ukur, vibrator, dan spatula.

Proses pembuatan tepung daun kelor diawali dari memilih daun segar berwarna hijau, kemudian dicuci hingga bersih, disortasi dan perontokan dari tangkai, kemudian ditebar diatas talang oven, lalu dikeringkan menggunakan kabinet dryer dengan suhu $45^{\circ}-50^{\circ} \mathrm{C}$ selama $16-18$ jam, penepungan dilakukan dengan menggunakan blender kering, lalu diayak menggunakan ayakan 60 mesh (Zakaria, 2012). Pembuatan tepung beras merah yaitu bersihkan terlebih dahulu beras merah dengan cara ditampi, setelah itu direndam selama 12 jam pada suhu kamar, selanjutnya ditiriskan dan digiling dengan mesin penepung, lalu dijemur sampai kering, setelah kering dilanjutkan pengayakan ukuran 60 mesh, tepung beras merah kemudian di sangrai. Bubuk beras merah instan. (Santoso, dkk 2007, modifikasi). Proses pembuatan bubuk bayi instan dengan campuran bubuk instan yaitu tepung beras merah dan tepung daun kelor. Pertama bahan baku tepung beras merah dan tepung daun kelor di sangrai, kemudian masing-masing bahan di timbang sesuai dengan formulasi dan campurkan semua bahan baku dan bahan campuran yaitu gula dan susu full cream, diaduk hingga merata (mix), MP-ASI bubuk instan, disajikan MP-ASI siap 
konsumsi dengan air hangat perbandingan (1:1). (Yustiani 2013, modifikasi).

Penelitian ini dilaksanakan pada bulan Februari sampai Juni 2018. Pembuatan produk, analisis fisik dan daya terima dilaksanakan di Laboratorium teknologi Pangan dan Gizi, Karakteristik kimia (kandungan gizi) pada tepung beras merah dan tepung daun kelor dianalisis di Laboratorium Kimia Sekolah Menengah Kejuruan Industri. Formulasi bubuk instan dengan penambahan daun kelor sebagai MP-ASI yaitu F1 (75:5), F2 (72,5:7,5), F3
(70:10), dan F4 (67,5:12,5) untuk mencukupkan $100 \mathrm{~g}$ bahan ditambahkan bubuk full cream $15 \mathrm{~g}$ dan gula $5 \mathrm{~g}$. Karakteristik yang diuji kandungan gizi makro dan karakteristik fisik dan daya terima yang dinilai secara hedonik terhadap 30 panelis. Produk terbaik berdasarkan karakteristik yang dinilai menggunakan metode efektivitas De Garmo.

\section{HASIL}

Kandungan gizi bahan baku

Tabel 1.

Kandungan Zat Gizi (100 g) Bahan Baku

\begin{tabular}{lcc}
\hline \multicolumn{1}{c}{ Kandungan Zat Gizi } & Tepung beras merah & Tepung daun kelor \\
\hline Energi (Kkal) & 369,3 & 432,9 \\
Protein (\%) & 9,8 & 30,2 \\
Lemak (\%) & 7,8 & 11,9 \\
Serat (\%) & 20,4 & 20,9 \\
Karbohidrat (\%) & 65 & 51,6 \\
Kadar Air (\%) & 6,2 & 5.7 \\
Kadar Abu (\%) & 11,23 & 0,8 \\
\hline
\end{tabular}

Tabel 1. Menunjukkan kandungan energy dan zat gizi pada tepung beras merah berturu-turut Energi sebesar 369,3 Kkal, protein $9,83 \%$, lemak $7,8 \%$, serat $20,4 \%$, karbohidrat $65 \%$, kadar air dan abu masing-masing $6,2 \%$ dan $11,2 \%$. Tepung daun kelor mengandung energy dan zat gizi berturut-turut Energi $432 \mathrm{Kkal}$, protein $30,2 \%$, lemak $11,9 \%$, serat 20,9 $\%$, karbohidrat $51,6 \%$. kadar air dan abu masing-masing $5,7 \%$ dan $0,8 \%$.
Kandungan gizi MP-ASI bubuk instan lokal menggunakan campuran tepung beras merah dan tepung daun kelor dalam $100 \mathrm{~g}$ bahan dengan rata-rata pada semua formulasi adalah kandungan energi $395,5 \mathrm{kkal}$, kadar protein 13,3 gram, kadar lemak $11,1 \mathrm{~g}$, karbohidrat 61,08 g sudah memenuhi syarat standard SNI, sedangkan kadar air 5,4 \%, kadar abu 8,1 \%, dan kadar serat $16,3 \mathrm{~g}$ belum memenuhi standard SNI (Tabel 2). 
Tabel 2.

Komposisi Gizi MP-ASI Bubuk Instan per 100 gram

\begin{tabular}{lccccc}
\hline \hline Komposisi & $\begin{array}{c}\text { Standar } \\
\text { SNI }\end{array}$ & Formula 1 & Formula 2 & Formula 3 & Formula 4 \\
\hline Protein $(\mathrm{g})$ & $8-22$ & 12,57 & 13,08 & 13,58 & 14,09 \\
\hline Lemak $(\mathrm{g})$ & $6-15$ & 10,92 & 11,02 & 11,12 & 11,22 \\
\hline Serat kasar $(\mathrm{g})$ & $\leq 5$ & 16,33 & 16,34 & 16,35 & 16,37 \\
\hline Kadar Air (\%) & 4,0 & 5,42 & 5,41 & 5,40 & 5,39 \\
\hline Kadar Abu (\%) & 3,50 & 8,46 & 8,20 & 7,94 & 7,68 \\
\hline Karbohidrat total (g) & 30 & 61,55 & 61,22 & 60,88 & 60,55 \\
\hline Tot.energi (kkal) & $400-440$ & 393,19 & 394,78 & 396,37 & 397,96 \\
\hline
\end{tabular}

Karakteristik fisik MP-ASI bubuk instan lokal densitas kamba F1, F2, F3, dan $\mathrm{F} 4$ rata-rata $0,5 \mathrm{~g} / \mathrm{ml}$, sedangkan daya serap air yaitu $1 \mathrm{ml} / \mathrm{g}$ dengan uji daya seduh 1:1 dengan lama waktu merehidrasi F1 dan F2 17 detik dan F3 dan F4 adalah 23 detik (Tabel 3).

Tabel 3.

Karakteristik Fisik Produk MP-ASI Instan Lokal

\begin{tabular}{ccccc}
\hline \hline $\begin{array}{c}\text { Formulasi Bubuk } \\
\text { Instan }\end{array}$ & $\begin{array}{c}\text { Densitas } \\
\text { Kamba (g/ml) }\end{array}$ & $\begin{array}{c}\text { Daya Serap } \\
\text { Air (ml/g) }\end{array}$ & $\begin{array}{c}\text { Uji Daya } \\
\text { Seduh }\end{array}$ & $\begin{array}{c}\text { Uji } \\
\text { Rehidrasi } \\
\text { (dtk) }\end{array}$ \\
\hline F1 & 0,5 & 1 & $1: 1$ & 17,05 \\
F2 & 0,5 & 1 & $1: 1$ & 17,10 \\
F3 & 0,5 & 1 & $1: 1$ & 23,16 \\
F4 & 0,5 & 1 & $1: 1$ & 23,20 \\
\hline
\end{tabular}

Tabel 03.

Daya Terima MP-ASI Bubuk Instan Lokal

\begin{tabular}{clcccccccc}
\hline Daya & Hedonic & \multicolumn{2}{c}{ F1 (75:5) } & \multicolumn{2}{c}{ F2 (72,5:7,5) } & \multicolumn{2}{c}{ F3 (70:10) } & \multicolumn{2}{c}{ F4 (67,5: 12,5) } \\
\cline { 3 - 9 } Terima & Scale & $\mathrm{n}$ & $\%$ & $\mathrm{n}$ & $\%$ & $\mathrm{n}$ & $\%$ & $\mathrm{n}$ & $\%$ \\
\hline Warna & Suka & 26 & 87 & 24 & 80 & 24 & 80 & 23 & 77 \\
& Tidak suka & 4 & 13 & 6 & 20 & 6 & 20 & 7 & 23 \\
Armoa & Suka & 28 & 93 & 20 & 67 & 25 & 83 & 23 & 76 \\
& Tidak suka & 2 & 7 & 10 & 33 & 5 & 17 & 7 & 24 \\
Tekstury & Suka & 26 & 87 & 24 & 80 & 24 & 80 & 23 & 77 \\
& Tidak suka & 4 & 13 & 6 & 20 & 6 & 20 & 23 & 30 \\
Rasa & Suka & 20 & 66 & 23 & 77 & 16 & 53 & 11 & 37 \\
& Tidak suka & 10 & 34 & 7 & 23 & 14 & 47 & 19 & 63 \\
\hline
\end{tabular}

Daya terima MP-ASI bubuk instan lokal dari aspek warna, aroma, dan tekstur yang paling disukai adalah Formula 1. dan
Aspek rasa yang paling disukai oleh panelis adalah Formula 2. (Tabel 4). 
Tabel 04.

Komposisi Gizi Formula Terbaik MP-ASI Bubuk Instan Lokal Yang Di Hasilkan

\begin{tabular}{|c|c|c|c|c|}
\hline NO & Komposisi Gizi & $\begin{array}{l}\text { Perlakuan } \\
\text { Terbaik F1 }\end{array}$ & Standar & Keterangan \\
\hline 1 & Energi (kal) & 393,19 & 400 & Sesuai \\
\hline 2 & Protein $(\mathrm{g})$ & 9,27 & 8 & Sesuai \\
\hline 3 & Lemak $(\mathrm{g})$ & 9,42 & 6 & Sesuai \\
\hline 4 & Karbohidrat total (g) & 56,72 & 30 (sukrosa) & Sesuai \\
\hline 5 & Serat $(g)$ & 16,33 & 5 & Belum sesuai \\
\hline 6 & Kadar Air (\%) & 5,42 & 4 & Belum sesuai \\
\hline 7 & Kadar Abu (\%) & 8,46 & 3,50 & Belum sesuai \\
\hline 8 & Densitas kamba (g/ml) & 0,52 & 0,5 & Sesuai \\
\hline 9 & Daya serap air (ml/g) & 1 & - & Sesuai \\
\hline 10 & Warna & 3,1 & 3 & Sesuai \\
\hline 11 & Aroma & 3,1 & 3 & Sesuai \\
\hline 12 & Tekstur & 3,1 & 3 & Sesuai \\
\hline \multirow[t]{2}{*}{13} & Rasa & 2,8 & 3 & Sesuai \\
\hline & Nilai Hasil (Nh) & 0,59 & 1 & - \\
\hline
\end{tabular}

\section{PEMBAHASAN}

\section{Kandungan Zat Gizi}

Hasil penelitian menunjukkan bahwa kandungan kadar protein pada keempat formulasi : F1, F2, F3, dan F4 rata-rata $13,3 \mathrm{~g}$ sudah memenuhi standar. Perbedaan kandungan protein antar formula disebabkan oleh perbedaan tambahan tepung daun kelor. Syarat kadar lemak pada formulasi yaitu rata-rata 11,1 gram sudah memenuhi standar SNI (Badan Standarisasi Nasional, 2005). Kadar serat MP-ASI pada keempat formula rata-rata adalah sebesar $16 \%$ mengandung serat lebih tinggi dari pada standar yang ditentukan. Kandungan serat tinggi dapat menyebabkan rasa cepat kenyang karena serat mempunyai penyerapan air yang tinggi sehingga bayi cepat kenyang padahal asupan gizi belum terpenuhi (Hadianingsih, 2004).

Kebutuhan energi bayi berusia 6-8 bulan dibutuhkan sebesar 783 Kkal, Dierkirakan sebanhak 437 Kkal dapat dipenuhi asupan ASI setiap harinya, berarti masih kurang sebanyak 346 Kkal yang diharapkan dapat diperoleh dari MP-ASI. Kandungan energi pada formula terbaik sebesar 390 Kkal, sehingga dapat memenuhi kekurangan energi yang kurang dari asupan ASI.

\section{Karakteristik Fisik}

Densitas kamba bubuk instan pada semua formulasi diperoleh nilai rata-rata sebesar $0,5 \mathrm{~g} / \mathrm{ml}$. Hal ini menunjukkan bahwa produk terpilih memiliki nilai densitas kamba yang sesuai dengan rentang densitas kamba produk bubuk instan pada umumnya yaitu $0,30-0,50 \mathrm{~g} / \mathrm{ml}$ (Hadianingsih, 2004). Penelitian ini sejalan dengan hasil penelitian Maulida (2016) yaitu $0,48 \mathrm{~g} / \mathrm{ml}$ dan daya serap air $1 \mathrm{ml} / \mathrm{g}$ dengan rentang waktu penyeduhan 17-23 detik..

\section{Daya Terima}

Bubuk instan yang dibuat dengan campuran tepung beras merah dan tepung daun kelor yang paling banyak disukai dari aspek warna, aroma tekstur adalah Formulasi 1,Nampak bahwa semakin banyak konsentarasi penambahan daun kelor maka warna hijau semakin tua, aroma semakin kuat dan tekstur semakin kental. Warna daun kelor disebabkan karena kloforil atau pigmen hijau (Kurnianingsi, 2015). Nampaknya semakin 
banyak campuran tepung daun kelor yang ditambahkan pada produk bubuk instan panelis semakin tidak suka. Pada aspek rasa, panelis menyukai formula 2 dengan konsentrasi penambahan tepung daun kelor sebesar Penelitian ini sama halnya dengan hasil penelitian Maulida (2016),

\section{Formula Terbaik}

Terpilihnya MP-ASI bubuk instan dengan campuran tepung beras merah dan tepung daun kelor didasarkan atas hasil hasil perhitungan metode Indeks Efektivitas (De Garmo, dkk, 1984) dengan skor tertinggi nilai hitung $(\mathrm{Nh}=0,59)$ adalah Formula 1 dengan perbandingan $(75: 5)$,

\section{KESIMPULAN}

Penelitian menunjukkan bahwa formula MP-ASI Instan lokal yang terbaik dengan niai hitung (Nh) 0,59 yaitu Formula 1 dengan kandungan gizi berturutturut energi 393,2 kkal, protein 9,3 g, lemak 9,4 g, karbohidrat 56,3 g, serat 16,33 g, kadar air 5,4 \%, kadar abu 8,5\%. Karakteristik fisik berdasarkan densitas 0,5 $\mathrm{g} / \mathrm{ml}$ dan daya serap air $1 \mathrm{ml} / \mathrm{g}$. Daya terima formula terbaik berdasarkan aspek warna, aroma, tekstur, rasa tergolong suka. Namun Kandungan vitamin dan mineral belum analisa sehingga belum diketahui pengaruh penambahan kelor terhadap kadar vitamin dan mineral

\section{SARAN}

Bagi peneliti selanjutnya dapat melakukan uji analisis zat gizi mikro. Peneliti selanjutnya mampu melakukan uji daya terima atau uji comstok pada bayi untuk melihat tingkat kesukaan bayi.

\section{DAFTAR PUSTAKA}

Badan Standarisasi Nasional. 2005. "SNI Makanan Pendamping Air Susu Ibu (MP-ASI)-Bagian 1: Bubuk Instan."

Badan Standarisasi Nasional. 1992. "SNI 01-2896-1992: Cara Uji Cemaran Logam. Jakarta.
Departemen Kesehatan RI. 2006. Pedoman Umum Pemberian Makanan Pendamping Air Susu Ibu (MP-ASI) Local. jakarta.

De Garmo, W.G., E.D., Sulivan and J.R.Canada. 1984. Engineering Economy. New York: MacMian Publishing Company.

Hadianingsih N. 2004. "Optimasi Formula Makanan Pendamping ASI Dengan Menggunakan Response Surface Methodology." Sekolah Pascasarjana Institute Pertanian Bogor.

Kementerian Kesehatan RI. 2012. Pedoman Kegiatan Gizi Dalam Penanggulangan Bencana. jakarta.

Kementerian Kesehatan RI. 2017. "Laporan Hasil Pemantauan Status Gizi (PSG) Tahun 2016.” Hasil Pemantauan Status Gizi (PSG) Tahun 2016.

Kurnianingsi, S R, 2015. Pengaruh Penambahan Tepung Daun Kelor (Moringa Oleifera) Pada Karakteristik Fisikokimia Dan Sensoris Es Krim: Program Studi Teknologi Pangan Fakultas Teknologi Pertanian. Universitas Katolik Soegijapranata Semarang. (http://repository.unika.a c.id/200/1/09.70.0119\%20Sesilia\%20 Rahayu\%20Kurnianingsih\%20cover. pdf) diakses tanggal 20 Januari 2017

Nurul Maulida. 2016. "Formulasi Bubur Instan Dengan Penambahan Tepung Daun Kelor (Moringa Oleifera) Sebagai Makanan Tambahan Bagi Kelompok Rentang Gizi."

Santoso Umar, Murdaningsih Triastati, \&. Mudjisihono R. 2007. "Produksi Ekstrusi Berbasis Tepung Ubi Jalar."

World Health Organization. 2000. "Complementary Feeding: Family Foods for Breastfed Children. Department of Nutrition and Development." WHO. Geneva.

Yustiani dan Budi Setiawan. 2013. 
"Formulasi Bubur Instan Sumber Protein Menggunakan Komposit Tepung Kacang Merah Sebagai Makanan Pendamping ASI (MPASI)." Jurnal Gizi Dan Pangan 8(2):95-102.
Zakaria. 2012. "Penambahan Tepung Daun Kelor Pada Menu Makanan SehariHari Dalam Upaya Penanggulangan Gizi Kurang Pada Anak Balita." Media Gizi Pangan XIII:41-47. 